\title{
VECTOR VARIATIONAL-LIKE INEQUALITIES WITH RELAXED $\eta-\alpha$ PSEUDOMONOTONE MAPPINGS IN BANACH SPACES
}

\author{
KE-QING WU AND NAN-JING HUANG
}

\begin{abstract}
In this paper, we introduce two new concepts of relaxed $\eta$ - $\alpha$ pseudomonotonicity and relaxed $\eta-\alpha$ demipseudomonotonicity as well as two classes of vector variational-like inequalities with relaxed $\eta-\alpha$ peseudomonotone mappings and relaxed $\eta$ - $\alpha$ demipseudomonotone mappings in Banach spaces. By using KKM technique, we obtain the existence of solutions for vector variational-like inequalities with relaxed $\eta-\alpha$ pseudomonotone mappings in reflexive Banach spaces. We also show the solvability of vector variational-like inequalities with relaxed $\eta-\alpha$ demipseudomonotone mappings in reflexive Banach spaces by means of Kakutani-FanGlicksberg fixed-point theorem. The results presented in this paper extend and improve some corresponding results of several authors.
\end{abstract}

Mathematics subject classification (2000): 49J40, 47H10.

Key words and phrases: Vector variational-like inequality; relaxed $\eta-\alpha$ pseudomonotone mapping; relaxed $\eta-\alpha$ demipseudomonotone mapping; KKM mapping; fixed point theorem.

\section{REFERENCES}

[1] M. R. BAI, S. Z. ZHOU AND G. Y. NI, Variational-like inequalities with relaxed $\eta$ - $\alpha$ pseudomonotone mappings in Banach spaces, Appl. Math. Lett., 19(2006), 547-554.

[2] Y. Q. CHEN, On the semimonotone operator theory and applications, J. Math. Anal. Appl., 231 (1999), 177-192.

[3] G. Y. Chen, X. X. HuANG AND X. Q. YANG, Vector Optimization: Set-Valued and Variational Analysis, Springer-Verlag, Berlin, Heidelberg, 2005.

[4] G. Y. CHEN AND X. Q. YANG, The vector complementary problem and its equivalences with vector minimal element in ordered spaces, J. Math. Anal. Appl., 153 (1990), 136-158.

[5] S. S. ChANG, B. S. LEE AND Y. Q. CHEN, Variational inequalities for monotone operators in nonreflexive Banach Spaces, Appl. Math. Lett., 8 (1995), 29-34.

[6] R. W. Cottle AND J. C. YaO, Pseudomonotone complementarity problems in Hilbert spaces, J. Optim. Theory Appl., 78 (1992), 281-295.

[7] Y. P. FANG AND N. J. HUANG, Variational-like inequalities with generalized monotone mappings in Banach spaces, J. Optim. Theory Appl. 118 (2003), 327-338.

[8] Y. P. FANG AND N. J. HUANG, The vector F-complementary problems with demipseudomonotone mappings in Banach spaces, Appl. Math. Lett., 16 (2003), 1019-1024.

[9] F. GIANNESSI, Theorems of alterative, quadratic programs and complementarity problems, in: R. W. Cottle, F. Giannessi and J. L. Lions(Ed.), Variational Inequalities and Complementarity Problems, pp. 151-186, Wiley, New York, 1980.

[10] F. GIANNESSI, Vector Variational Inequalities and Vector Equilibria, Kluwer Academic Publishers, Dordrecht, Holland, 2000.

[11] A. Göpfert, H. Riahi, C. TAMmer and C. ZĂLINESCU, Variational Methods in Partially Ordered Spaces, Springer-Verlag, New York, 2003.

[12] N. HADIISAVVAS AND S. SCHAIBLE, Quasimonotone variational inequalities in Banach spaces, J. Optim. Theory Appl., 90 (1996), 95-111. 
[13] N. J. HUANG AND Y. P. FANG, On vector variational inequalities in reflexive Banach spaces, J. Global Optim., 32(2005), 495-505.

[14] N. J. HuANG AND Y. P. FANG, Strong vector F -complementary problem and least element of feasible set, Nonlinear Anal. TMA, 61 (2005), 901-918.

[15] N. J. HUANG AND C. J. GAO, Some generalized vector variational inequalities and complementarity problems for multivalued mappings, Appl. Math. Lett., 16 (2003), 1003-1010.

[16] S. Karamardian AND S. Schaible, Seven kinds of monotone maps, J. Optim. Theory Appl., 66 (1990), $37-46$.

[17] I. V. Konnov AND J. C. YaO, On the generalized vector variational inequality problems, J. Math. Anal. Appl., 206 (1997), 42-58.

[18] D. T. LuC, Existence results for densely pseudomonotone variational inequalities, J. Math. Anal. Appl., 254 (2001), 291-308.

[19] W. Rudin, Functional Analysis, McGraw-Hill Book Company, New York, 1973.

[20] R. U. VERMA, Nonlinear variational inequalities on convex subsets of Banach spaces, Appl. Math. Lett., 10 (1997), 25-27.

[21] R. U. Verma, On monotone nonlinear variational inequality problems, Comment. Math. Univ. Carolinae, 39 (1998), 91-98.

[22] J. C. YAO, Existence of generalized variational inequalities, Oper. Res. Lett., 15 (1994), 35-40.

[23] X. Q. YANG AND G. Y. CHEN, A class of nonconvex functions and prevariational inequalities, J. Math. Anal. Appl., 169 (1992), 359-373.

[24] G. X. Z. YUAN, KKM Theory and Applications in Nonlinear Analysis, Marcel-Dekker, New York, 1999. 